\title{
Perioperative management of anticoagulant users scheduled for glaucoma surgery: a survey among the Brazilian Glaucoma Society members
}

\author{
Condução de pacientes usuários de anticoagulantes no perioperatório de cirurgia antiglaucomatosa: \\ uma pesquisa entre os membros da Sociedade Brasileira de Glaucoma
}

Marcos Balbino ${ }^{1,2}$, Plinio Boin ${ }^{3}$, Tiago Santos Prata 2,3

\begin{abstract}
Purpose: To investigate and describe, among the members of the Brazilian Glaucoma Society (BGS), the practices regarding the perioperative management of anticoagulants (warfarin and aspirin) use in patients scheduled for glaucoma surgery.

Methods: The active members of the Brazilian Glaucoma Society answered a questionnaire evaluating different aspects of their current perioperative management of glaucomatous patients taking warfarin or aspirin.

Results: A total of 52 participants returned a complete questionnaire. Warfarin or aspirin was routinely interrupted prior to glaucoma surgery by $82.7 \%$ of the respondents. The majority of the surgeons who discontinued these medications reported doing so 7 days prior to surgery and resumed their use the day after the procedure. Almost half of our interviewees reported hemorrhagic complications that could be related to anticoagulant therapy. A large number of the surgeons (86.5\%) preferred a particular surgical technique for anticoagulated patients however, most of them (88.5\%) do not change the anesthetic planning in such patients. Finally, the majority of the participants (90.4\%) refer their anticoagulated patients to a preoperative appointment with a cardiologist or a general practitioner before the surgery.

Conclusions: The majority of Brazilian Glaucoma Society members participating in this study interrupt either warfarin or aspirin prior to glaucoma surgery. Although there is scant information available in the literature to offer definitive guidance most participants from the Brazilian Glaucoma Society seem to share the same opinion when it comes to perioperative management of anticoagulant users.
\end{abstract}

Keywords: Anticoagulants/adverse effects; Aspirin; Warfarin; Glaucoma/surgery; Cataract extraction; Perioperative period; Societies, medical; Questionnaires

\section{RESUMO}

Objetivo: Investigare descrever, entreos membros da Sociedade Brasileira de Glaucoma $(S B G)$, as práticas relativas ao manejo de anticoagulantes (varfarina e aspirina) em pacientes agendados para cirurgia antiglaucomatosa.

Métodos: Foi enviado um questionário objetivo aos membros ativos da Sociedade Brasileira de Glaucoma avaliando diferentes aspectos da forma como conduzem seus pacientes em uso de varfarina ou aspirina durante o período perioperatório de uma cirurgia antiglaucomatosa.

Resultados: Cinquenta e dois participantes retornaram o questionário preenchido adequadamente. O uso de varfarina ou aspirin a foi rotineiramente interrompido antes da cirurgia antiglaucomatosa por $82,7 \%$ dos entrevistados. A maior parte dos cirurgiões, quando interromperam o uso destes medicamentos, o fez sete dias antes da cirurgia e os reintroduziram no dia seguinte ao procedimento. Aproximadamente metade dos entrevistados disse ter observado complicações hemorrágicas que poderiam ser relacionados à terapia anticoagulante. Embora a maioria dos cirurgiões $(86,5 \%)$ referiu utilizar alguma técnica cirúrgica em particular para esses pacientes anticoagulados, quase todos $(88,5 \%)$ não alteram seu planejamento anestésico de rotina nesses mesmos casos. Finalmente, a maior parte dos participantes (90,4\%) relatou referir seus pacientes anticoagulados para uma avaliação pré-operatória com um cardiologista ou um clínico geral.

Conclusão: A maior parte dos membros da Sociedade Brasileira de Glaucoma que participou desse estudo refere interromper o uso de anticoagulantes (varfarina ou aspirina) antes de uma cirurgia antiglaucomatosa. Embora existam poucas informações disponíveis na literatura para oferecer uma orientação definitiva, a maioria dos participantes parece compartilhar da mesma opinião quando se trata do manejo perioperatório de anticoagulantes.

Descritores: Anticoagulantes/efeitos adversos; Aspirina; Varfarina; Glaucoma/cirurgia; Extração de catarata; Período perioperatório; Sociedades médicas; Questionários

\section{INTRODUCTION}

Prophylactic anticoagulation has been of paramount importance in preventing coronary ischemic events, stroke and peripheral arterial obstruction. Moreover, since the advent of coronary stenting, these drugs have become fundamental as adjuvants to this invasive approach to coronary disorders. Each year, anticoagulant therapy is used to protect millions of cardiac patients from direct artery obstruction or reocclusion after implanting a stent ${ }^{(1,2)}$. On the other hand, it is well known that anticoagulated patients are exposed to a greater risk of hemorrhages when submitted to incisional surgeries ${ }^{(3)}$.
The general perioperative management of anticoagulated patients has been described previously in details ${ }^{(3)}$. In ophthalmological surgeries, there are some data postulating the safety in maintaining anticoagulants before cataract surgery ${ }^{(3,4)}$; however, there is little information available to offer definitive guidance in glaucoma surgery $^{(5)}$, as well as in retina surgery ${ }^{(6)}$.

The purpose of the present study was to evaluate the current routine of glaucoma surgeons in Brazil regarding the use of anticoagulants in patients scheduled for glaucoma surgery. The study was based on data collected from the members of the Brazilian Glauco- 
ma Society (BGS) and aimed to investigate different aspects of their perioperative management of glaucomatous patients taking two commonly used anticoagulants: warfarin and aspirin.

\section{METHODS}

An email containing a 9-item questionnaire was adapted from a previous paper, which surveyed cataract surgeons facing anticoagulated patients submitted to cataract surgery ${ }^{(7)}$. The main data collected were the percentage of surgeons who routinely withhold warfarin or aspirin before surgery, the number of days prior to surgery that anticoagulants are discontinued; as well as the number of days after surgery in which such drugs are resumed. Additional information included the frequency of complications associated either with the maintenance or the stopping of anticoagulants, possible changes in surgeon's usual anesthesia procedure and need of preoperative appointment with a cardiologist or a general practitioner prior to surgery.

The questionnaire was sent by email to all ophthalmologists affiliated to the BGS. The survey was self administered and confidential, with no reminder letters sent. Even though there were 580 active members in the society at that time, approximately $30 \%$ could not be reached (due to full mailbox, wrong email address or Internet server issues). Replies were collected over 2 months. In the last BGS meeting, more specialists were stimulated to participate. All data were entered and analyzed in an Excel database, and descriptive analysis was used to summarize the results of the survey. Only full-filled questionnaires were considered for analysis.

\section{RESULTS}

A total of 52 participants returned a complete questionnaire, resulting in a response rate of approximately $13 \%$.

When asking about interrupting anticoagulation drugs, $82.7 \%$ (42 out of 52) said they interrupted both aspirin and warfarin before operating on these patients, and the remaining $17.3 \%$ (9 out of 52) kept such medications throughout the perioperative period. Among those who interrupted anticoagulants, the majority (36 out of 52, corresponding to 69.2\%) did so seven days before surgery, interrupting both aspirin and warfarin. Three participants (5.8\%) interrupted anticoagulants for 10 days, and one (1.9\%) did so for 15 days. Finally, three (5.8\%) suspended the drugs for up to 5 days before the procedure (Table 1). Regarding the participants who suspended the anticoagulants, most of them resumed such drugs in the following manner: 24 (55.8\%) reintroduced the drugs 1 day after the procedure, 4 (9.3\%) after 2-5 days, and 9 (20.9\%) after 7 days.

Twenty-seven respondents (51.9\%) experienced hemorrhagic complications that may have been related to anticoagulation therapy. There were participants who reported more than one hemorrhagic event. Among them, 8 (29.6\%) reported the occurrence of excessive subconjunctival hemorrhage (one of them noticed hemorrhage at the filtration bleb); 7 (25.9\%) reported the occurrence of hyphema, $8(29.6 \%)$ described cases of increased postoperative bleeding and two (7.4\%) reported a hemorrhagic choroidal detachment. There were three reports $(11.1 \%)$ of hemorrhage related to the needlebased eye block.

Table 1. Routine anticoagulation management prior to glaucoma surgery

\begin{tabular}{lc}
\hline Anticoagulation management & Percentage of participants \\
\hline Withhold treatment 10 days or more before surgery & $7.7 \%(4 / 52)$ \\
Withhold treatment 7 days before surgery & $69.2 \%(36 / 52)$ \\
Withhold treatment up to 5 days before surgery & $5.8 \%(3 / 52)$ \\
Do not withhold anticoagulant therapy & $17.3 \%(9 / 52)$ \\
\hline
\end{tabular}

Anticoagulation was not a reason for choosing a specific anesthetic planning to the vast majority of the surgeons, as 47 (90.4\%) of them did not change their usual anesthesia procedure. According to the participants, $38(73.1 \%)$ preferred injectable anesthesia while $12(23.1 \%)$ preferred topical anesthesia and only two (3.8\%) chose general anesthesia. The surgical procedure itself can vary according to the presence of anticoagulants: 45 participants (86.5\%) preferred a particular incision type in these patients, whereas 7 (13.5\%) did not change their technique. Finally, the majority of the participants (90.3\%) referred their anticoagulated patients to a preoperative appointment with a cardiologist or a general practitioner prior to the surgery.

\section{DISCUSSION}

The perioperative management of patients who require temporary interruption of vitamin $\mathrm{K}$ antagonists or antiplatelet drugs because of a surgical procedure is a common and challenging clinical problem ${ }^{(2)}$. The number of such patients has increased over the last decade, due to cardiovascular diseases (atrial fibrillation, mechanical heart valve) or percutaneous coronary intervention; therefore, these patients are no longer the tiny minority of the non-cardiac surgical candidates. A multicenter audit has shown that $28.1 \%$ and $5.1 \%$ of 48,862 patients submitted to cataract surgery were taking aspirin or warfarin, respectively ${ }^{(8)}$.

The rare occurrence of serious hemorrhagic complications with visual impairment in patients who keep aspirin or warfarin throughout the perioperative period has been shown before ${ }^{(7,9)}$. An EvidenceBased Clinical Practice Guideline suggested (a Grade $1 \mathrm{C}$ recommendation) that patients undergoing cataract extraction who are under warfarin or aspirin should continue their anticoagulants around the time of the procedure ${ }^{(2)}$. Anticoagulants were also advised to be maintained even in cases of 25-gauge vitrectomy, in which the frequency of serious hemorrhagic complications were extremely low ${ }^{(10)}$. Unfortunately, there are scant data available for such patients when it comes to glaucoma surgery.

In a previous survey done in the United Kingdom, questionnaires were sent to ophthalmologists with a special interest in glaucoma ${ }^{(5)}$. Approximately $30 \%$ of the respondents stop either warfarin or aspirin, for 4 and 7 days prior to surgery, respectively. These numbers are significantly lower when compared to the responses of most of the participants from our study, as over $80 \%$ are prone to interrupt both drugs, and most of them do so for seven days before surgery. We believe the main reason for this difference could be related to the fact that a significant percentage of the participants in our study (approximately half of them) have experienced hemorrhagic complications in their anticoagulated patients during or after a glaucoma surgery. Another interesting difference between these two studies is that while most of the interviewees in our study (over 90\%) required a cardiologist or a general practitioner opinion when dealing with anticoagulated patients prior to glaucoma surgery (even though there is no official guideline for this), only $23.8 \%$ of the respondents from the British survey ${ }^{(5)}$ usually rely on a second opinion (in fact, an hematologist was the specialist required in that study).

We found that the majority of BGS members interviewed preferred injectable anesthesia. A large study analyzed more than 14,000 peribulbar/retrobulbar anesthesias in a cohort where $24.2 \%$ and $4 \%$ of the patients were on aspirin or warfarin, respectively. Hemorrhage rate in that study due to the anesthesia was found to be extremely low ${ }^{(4)}$. However, as discussed previously, not only anesthesia related hemorrhages can occur in anticoagulated patients, but also those related to the surgical manipulation itself. The later seem to be even more important in these cases, as approximately half of the BGS members interviewed reported some type of hemorrhagic complication (from subconjunctival hemorrhage to choroidal detachment). In this context, a previous report have alerted to the risk of excessive 
hemorrhage during glaucoma surgery in anticoagulated patients, especially in those taking warfarin ${ }^{(11)}$.

The main drawback of our paper is its low response rate (13\%) and number of participants $(n=52)$, which should be considered while interpreting our results. Looking carefully at the related literature, response rates of ophthalmological surveys seem to vary significantly. For instance, while a small survey among cataract surgeons in Singapore reported a response rate of $61 \%^{(12)}$, a large study in the USA among the American Society of Cataract and Refractive Surgery (ASCRS) members had a much lower rate, of approximately $15 \%{ }^{(13)}$. Interestingly, the later study is a traditional survey, which had been applied and reported annually since $1985^{(14)}$. We believe that different factors might have partially contributed to the low response rate we have obtained. First, glaucoma specialists in general could not be used to this type of surgical survey. While there are many previously published surgical surveys among cataract surgeons, a significant proportion of the surveys among glaucoma specialists have focused on the clinical management of the disease (drug preferences), and not on surgical preferences. Second, this type of study design is not a usual practice in Brazil, as there are few publications available in the ophthalmological literature based on questionnaire responses (surveys). In addition, some of the participants could not be familiar or even comfortable while dealing with an Internet based approach. Third, differently from cataract specialists, not every glaucoma specialist performs surgical procedures. We believe that a significant proportion of the BGS members might not be composed by active glaucoma surgeons. Finally, two other aspects or limitations of our study should be considered as they might have influenced our results. We assessed the management of anticoagulants considering warfarin and aspirin in conjunction. Therefore, we could not determine whether a respondent would have a different approach for each anticoagulant drug. In addition, due to the study design (Survey), glaucoma specialists that had previous hemorrhagic complications usually tend to participate more than those who never experienced such problems. This fact (bias) might have increased the percentage of hemorrhagic events reported in our study.

\section{CONCLUSION}

In sum, the majority of the BGS members interviewed interrupt anticoagulant drugs before a glaucoma surgery. Most of the ophthalmologists withhold either warfarin or aspirin for seven days. Ninety percent require a cardiologist or a general practitioner opinion prior to the surgery. Hemorrhagic surgical complications were reported by approximately half of the interviewees. Currently, the management of anticoagulated patients scheduled for glaucoma surgery has no specific recommendation. Possibly, these patients are exposed to a higher risk, and further studies are necessary to establish a definitive medical management protocol.

\section{REFERENCES}

1. Chassot PG, Marcucci C, Delabays A, Spahn DR. Perioperative antiplatelet therapy. Am Fam Physician. 2010;82(12):1484-9.

2. Douketis JD, Berger PB, Dunn AS, Jaffer AK, Spyropoulos AC, Becker RC, Ansell J; American College of Chest Physicians. The perioperative management of antithrombotic therapy: American College of Chest Physicians Evidence-Based Clinical Practice Guidelines (8th Edition). Chest. 2008;133(6 Suppl):299S-339S.

3. Dunn AS, Turpie AG. Perioperative management of patients receiving oral anticoagulants: a systematic review. Arch Intern Med. 2003;163(8):901-8. Comment in: Evid Based Dent. 2005;6(1):11; Arch Intern Med. 2003;163(20):2532; author reply 2533; Arch Intern Med. 2003;163(20):2532-3; author reply 2533; Arch Intern Med. 2003; 163(8):881-3

4. Katz J, Feldman MA, Bass EB, Lubomski LH, Tielsch JM, Petty BG, Fleisher LA, Schein OD; Study of Medical Testing for Cataract Surgery Team. Risks and benefits of anticoagulant and antiplatelet medication use before cataract surgery. Ophthalmology. 2003;110(9):1784-8. Erratum in: Ophthalmology. 2003;110(12):2309. Comment in: J Fam Pract. 2003;52(12):933-5; Ophthalmology. 2004;111(8):1618-9; author reply 1619.

5. Alwitry A, King AJ, Vernon SA. Anticoagulation therapy in glaucoma surgery. Graefes Arch Clin Exp Ophthalmol. 2008:246(6):891-6.

6. Oh J, Smiddy WE, Kim SS. Antiplatelet and anticoagulation therapy in vitreoretinal surgery. Am J Ophthalmol. 2011;151(6):934-9. Comment in: Am J Ophthalmol. 2012; 153(1):185-6; author reply 186-7.

7. Ong-Tone L, Paluck EC, Hart-Mitchell RD. Perioperative use of warfarin and aspirin in cataract surgery by Canadian Society of Cataract and Refractive Surgery members: survey. J Cataract Refract Surg. 2005;31(5):991-6.

8. Benzimra JD, Johnston RL, Jaycock P, Galloway PH, Lambert G, Chung AK, Eke T, Sparrow JM; EPR User Group. The Cataract National Dataset electronic multicenter audit of 55,567 operations: antiplatelet and anticoagulant medications. Eye (Lond). 2009;23(1):10-6.

9. Chassot PG, Delabays A, Spahn DR. Perioperative antiplatelet therapy: the case for continuing therapy in patients at risk of myocardial infarction. $\mathrm{Br} J$ Anaesth. 2007; 99(3):316-28.

10. Mason JO 3rd, Gupta SR, Compton CJ, Frederick PA, Neimkin MG, Hill ML, et al. Comparison of hemorrhagic complications of warfarin and clopidogrel bisulfate in 25-gauge vitrectomy versus a control group. Ophthalmology. 2011;118(3):543-7.

11. Cobb CJ, Chakrabarti S, Chadha V, Sanders R. The effect of aspirin and warfarin therapy in trabeculectomy. Eye (Lond). 2007;21(5):598-603.

12. Wagle AA, Wagle AM, Bacsal K, Tan CS, Chee SP, Au Eong KG. Practice preferences of ophthalmic anaesthesia for cataract surgery in Singapore. Singapore Med J. 2007; 48(4):287-90.

13. Leaming DV. Practice styles and preferences of ASCRS members-2003 survey. J Cataract Refract Surg. 2004;30(4):892-900

14. Leaming DV. Practice styles and preferences of ASCRS members-1985 survey. J Cataract Refract Surg. 1986;12(4):380-4 